\title{
Cognitive and behavioral manifestations in SARS-CoV-2 infection: not specific or distinctive features?
}

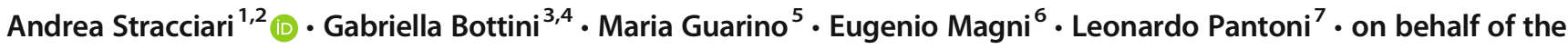 \\ "Cognitive and Behavioral Neurology" Study Group of the Italian Neurological Society
}

Received: 19 January 2021 / Accepted: 6 April 2021 / Published online: 12 April 2021

(C) Fondazione Società Italiana di Neurologia 2021

\begin{abstract}
Patients with COVID-19 are increasingly reported to suffer from a wide range of neurological complications, affecting both the central and peripheral nervous system. Among central manifestations, cognitive and behavioral symptoms are to date not exhaustively detailed. Furthermore, it is not clear whether these represent a combination of non-specific complications of a severe systemic disease, not differing from those usually seen in patients suffering from heterogenous pathological conditions affecting the central nervous system, or instead, they are a peculiar expression of COVID-19 neurotropism; in other words, if the infection has a coincidental or causal role in such patients. We examined both hypotheses, reporting opposite points of view, with the aim to stimulate discussion and raise awareness of the topic.
\end{abstract}

Keywords COVID-19 $\cdot$ Neurological complications $\cdot$ Cognitive disorders $\cdot$ Behavioral manifestations $\cdot$ Encephalopathy

\section{Introduction}

The COVID-19 pandemic, caused by the novel coronavirus named "severe acute respiratory syndrome coronavirus 2 " (SARS-CoV-2), has resulted to date in more than 68 million confirmed cases worldwide and more than 1.5 million deaths

This study is based on a webinar meeting of the Italian Neurological Society held on June 16, 2020.

Andrea Stracciari andreastracciari@alice.it

1 University of Bologna, Bologna, Italy

2 Chair of the "Cognitive and Behavioral Neurology" Study Group of the Italian Neurological Society, Bologna, Italy

3 Neuroscience and Society Lab, Brain and Behavioral Sciences Department, University of Pavia, Pavia, Italy

4 Cognitive Neuropsychology Center, Niguarda Ca' Granda Hospital, Milan, Italy

5 IRCCS Istituto delle Scienze Neurologiche di Bologna, Neurology Unit, S. Orsola-Malpighi University Hospital, Bologna, Italy

6 Department of Neuroscience, "Poliambulanza" Foundation, Brescia, Italy

7 Stroke and Dementia Lab, "Luigi Sacco" Department of Biomedical and Clinical Sciences, University of Milan, Milano, Italy
(WHO daily report, December 9, 2020), raising significant public health and economic concerns overwhelming the health systems all over the world. Beside the canonical and usually severe symptoms due to the respiratory apparatus involvement $[1,2]$, it has rapidly become clear that the virus impairs other districts, inducing a complex systemic pathological condition difficult to manage [3-6]. Among these extrapulmonary conditions, neurologic involvement has been increasingly observed. Literature reports on the possible neurological complications of SARS-CoV-2 infection have multiplied over the last months: a Pubmed search with the keywords "COVID" and "neurology" yielded 116 papers as of May 2, 2020, while the same research performed on December 9 led to find 2326 papers. These reports included mostly single cases, small samples, and retrospective numerically limited case series [7-22]; however, not all giving exhaustive details of both clinical features and diagnostic investigations [23]. It is quite evident that, under these circumstances, a critical assessment of the literature on this topic is rather difficult. Notwithstanding this, it seems clear that the neurological manifestations of COVID-19 include a wide heterogeneous range of both central (CNS) and peripheral nervous system (PNS) features, such as disturbances of consciousness, headache, dizziness, seizures, fatigue, cerebrovascular disease, encephalopathy, encephalitis, anosmia and dysgeusia, polyradicoloneuritis, myelitis, and myopathies. 
Among CNS symptoms, cognitive and/or behavioral disturbances during COVID-19 have been usually collected under the umbrella term of encephalopathy, referring to impaired consciousness, altered mental status, confusion, agitation, delirium, or at best indicated as dysexecutive syndrome. No exhaustive clinical - especially neurobehavioral - details were given and only few reports included a comprehensive description of cerebro-spinal fluid (CSF) analysis, imaging, or follow-up, reflecting the challenge of studying such patients. Neuropathological findings should be considered with caution, given the great variability in the procedures of tissues examination, and the heterogeneity of ancillary studies performed. Inflammatory changes have been densely reported in some series but not in others, in part due to the use of immunostaining. Furthermore, the lack of controls in most of the studies limits the interpretation of the results. Activation of microglia, variable degrees of astrogliosis, and infiltration with $\mathrm{CD} 8$-positive $\mathrm{T}$ cells are the main findings reported in the most comprehensive neuropathological study of patients who died from COVID-19 [24]. SARS-CoV-2 RNA and proteins in the brains of patients with COVID-19 has been detected in some patients, but this was not associated with the severity of neuropathological changes [24].

This data may warrant the idea of non-specific symptoms, related to those mechanisms usually acting in the intensive care unit (ICU), such as critical illness, hypoxia, multiorgan failure, and sepsis, among others. It has been also proven that COVID-19 can involve the CNS at a different level, by causing in the infected patients various degrees of behavioral distress associated with increase in inflammation markers, such as depression, anxiety, fatigue, and post-traumatic stress disorder, even after being discharged from the hospital [25]. On the other hand, a few recent observations describe peculiar neuropsychological features in patients affected by COVID19 , raising the possibility of specific neurocognitive and behavioral syndromes.

Our aim was to review the current literature on this topic, trying to analyze and discuss both hypotheses in the form of a courtroom challenge, enhancing contrasting opinions (CONS and PROS) on the specificity of presenting neurocognitive and neurobehavioral symptoms in COVID-19 patients.

\section{CONS: cognitive and behavioral manifestations of COVID-19 are not specific and clinically not relevant ${ }^{1}$}

The nature of cognitive and behavioral symptoms during SARS-CoV-2 infection appears to be related to two possible main mechanisms: brain suffering secondary to general medical conditions (such as hypoxia, drug side effects, and fever)

\footnotetext{
${ }^{1}$ This position is mainly sustained by LP and EM.
}

and to a truly primary damage such as in the cases of encephalitis especially when significant pulmonary or systemic involvement is lacking.

On the one hand, delirium best represents an example of aspecific cognitive failure caused by a variety of non-primarily neurologic conditions. During the pandemic, delirium was the most common behavioral manifestation in COVID-19 patients, with up to $11 \%$ of incidence during hospitalization, with the elderly more frequently affected $[26,27]$. Delirium might not be specific to COVID-19, since a high rate of neurological dysfunctions is reported in many other acute and severe conditions, particularly in the setting of acute respiratory distress syndrome (ARDS), both in terms of delirium in the acute phase [28] and cognitive sequelae in the chronic one [29].

Furthermore, pre-existing cognitive situations should always be considered when observing the new onset of neurological dysfunctions: patients with pre-existing dementia have shown to have high rate of delirium and worsening in the functional status on the occurrence of COVID-19 [30]. Last but not least, the sole effects of hypoxia on the brain should always be pondered [31], since that the main cause of alterated consciousness or encephalopathy, especially in ICU, is represented by the hypoxic/ischemic brain damage due to cardiac arrest, severe hypotension, blood loss, severe infection, or shock [32].

On the other hand, in COVID-related encephalitis (a definitely less common complication of SARS-CoV-2 infection with an estimated incidence of 58/100,000 cases), a direct neuronal injury causes focal or global cognitive manifestations such as delirium, lethargy, dysatrhia in association with seizures, and movement disorders [33]. These symptoms, however, are not distinctive being common in encephalitis caused by other agents. Given the rather scant, if any, demonstration of a direct effect of the virus on the CNS, other mechanisms might be hypothesized, such as the involvement of inflammation and immune-mediated effects. The occurrence of a "cytokine storm" leading to "sickness behavior" has been postulated in other ARDSs [34]. In an early study [9], authors were not able to detect the virus in the CSF of 7 patients, all with severe neurological involvement. Also in another series, COVID-19 RNA was not detected in the CSF of 25 encephalitis patients [33]. Similar results have been reported by another recent study in which the authors basically found only signs of indirect immunological involvement of the central nervous system without detection of the etiologic agent in the CSF [35]. A neuropathological study of 43 consecutive patients with COVID-19 (24) showed mild changes with pronounced neuroinflammatory features in the brainstem. No evidence for CNS damage directly caused by SARS-CoV-2 were detected, thus suggesting that CNS damage and neurological symptoms might be due to additional factors. 
The direct involvement of the CNS by SARS-CoV-2 was initially hypothesized in the so-called smell and/or taste disorders (STD) that have been extensively reported by COVID19 patients. However, only in one single case report was the authors able to show on brain MRI a cortical hyperintensity in the right gyrus rectus and a subtle hyperintensity in the olfactory bulbs which they felt suggestive of viral infection [36]. Moreover, Eliezer et al. [37] demonstrated that COVID-19 patients with STD presented edema in the olfactory cleft and this is why the core nature of the disturbance remains rather uncertain. In this complex and unexplored situation, there is, in fact, the risk of a "covidization" of all disturbances as exemplified in some recent reports, i.e., that everything is causally attributed to this virus $[38,39]$.

Finally, when approaching and evaluating the effects of the current pandemic on behavior and cognition, we need to consider also the direct and indirect effects of the restriction measures that have been adopted and that might be adopted again in the future by the Governments. Lockdown is a glaring example, although not the only one. In a cohort of 40 patients with Alzheimer's disease or mild cognitive impairment without SARS-CoV-2 infection, worsening of neuropsychiatric symptoms during the 5 weeks of lockdown was shown, with agitation, apathy, and aberrant motor activity being the most common symptoms [40]. Nonetheless, what we observe might not be specific to the COVID-19 pandemic because a review of 24 studies on the psychological impact of quarantine including people with SARS, MERS, Ebola, H1N1 influenza, and equine influenza reported negative psychological effects including post-traumatic stress symptoms, confusion, and anger [41].

Long-term cognitive effects are often seen following ICU admission and severe viral infection, as part of post intensive care syndrome and post-viral syndrome, respectively. Both syndromes are associated with worsened physical, cognitive, and mental health outcomes, persisting beyond the initial illness. Up to $80 \%$ of patients experiencing ARDS and mechanical ventilation exhibit post intensive care cognitive and behavioral syndrome, often involving memory, attention, speed processing, and executive functioning, both at 3 and 12 months after discharge [42]. Whether cognitive impairment is due to the virus itself, rather than ICU admission, is unclear. Studies on cognitive functions after COVID-19 infection are scarce and limited to small samples and short-term follow-up. Cognitive assessments are not always adequate. One study of 29 outpatients indicated deficits in sustained attention and reaction times [43], while another study of nine patients found impairment in global cognitive function, including attention, memory, language, and praxis [44].

Cognitive dysfunction mainly concerning memory, attention, and executive functions has been reported in 35 COVID19 patients in a very short-term period after discharge [45], but long-term effect was unknown.
Thus, neuropsychological impairment after COVID-19 seems similar to that following critical illness. In fact, multiple factors associated with the illness may contribute to cognitive sequelae, e.g., hypoxia, ventilation, sedation, delirium, cerebrovascular events, and inflammation, but further studies on large sample and long-term follow-up are needed.

In conclusion, independently from the suspected mechanism underlying neurological dysfunction, we could not find any behavioral or cognitive marker specific to COVID-19. We need stronger data before attributing any specific cognitive pattern to SARS-CoV-2; we also need to better understand the possible underlying mechanisms that might link this infection with CNS disturbances.

\section{PROS: cognitive and behavioral manifestations of COVID-19 are relevant and quite distinctive ${ }^{2}$}

The appearance of specific symptoms such as anosmia and ageusia drove the researchers' attention to the possible neurotropism of SARS-CoV-2 and called for further investigations to better understand the causes of morbidity and mortality of patients infected by this virus [46]. It is true that anosmia is fairly frequent in viral infections involving the high respiratory tract, due to the abundant rhinorrhea [47]; however, in the case of COVID-19, this olfactory dysfunction unlikely depends on peripheral events as the inflammatory production and the associated nasal obstruction is very limited [48]. Furthermore, anosmia mostly occurs in association with gustatory deficits, as demonstrated by a recent multicenter European study investigating the presence of these symptoms through a clinical questionnaire [49]. Speculating on the pathophysiology of such symptoms, the virus may infect peripheral neurons and actively access the CNS.

Taking into consideration the neurological symptoms observed during the infection, we can distinguish general symptoms of the acute phase - e.g., headache, vomiting, and seizures - and particular symptoms or syndromes emerging during the course of the illness. The spectrum of acute CNS dysfunctions seems to suggest direct viral invasion, but the virus has been only occasionally isolated into the CSF of patients showing neurological symptoms, in particular meningitis and encephalitis [7], and the mechanisms underpinning SARS-CoV-2 infection are still unclear [50]. SARS-CoV-2 is structurally similar to SARS-CoV, as both bind to the angiotensin-converting enzyme 2 (ACE2) receptors [51]. It has not been fully clarified whether the most characteristic extra neurologic symptom of patients, i.e., respiratory distress, may also depend on the potential SARS-CoV-2 invasion of the CNS, in particular of the medullary neurons [52]. The

\footnotetext{
${ }^{2}$ This position is mainly sustained by GB and MG.
} 
origin of neurological clinical manifestations often has not been fully investigated through the CSF analysis or cerebral MRI scans, leaving doubts about the pathogenetic diagnosis.

Among the neurological manifestations of COVID-19, acute/subacute encephalopathy has been frequently reported, ranging from 7 to $31 \%$ of consecutive clinical series [2,52], and it may inaugurate the infection with SARS-CoV-2 [53]. It can present with delirium and agitation or alternatively severe psychomotor retardation with abulia and catatonia-like status. Additional manifestations may include seizures, myoclonus, headache, or pyramidal and extrapyramidal signs. In the firstly reported patients with COVID-19 and encephalopathy, no clinical details on mental status were given except for generic consciousness impairment, reasonably due to the severity of the pandemic, which in many cases did not permit the investigations to better explore and detail cerebral involvement. Recent observations report a more detailed comprehensive description of clinical pictures and CSF analysis, neuroimaging, and follow-up, favoring a better prominent "frontal" behavioral disorders emerge as the clinical core of subacute COVID-19-related encephalopathy, at least for a nonnegligible subgroup of patients $[9,15,54-62]$. As new cases are added, language disturbances have been increasingly observed as a distinctive and early sign in COVID-19-related encephalopathy [9, 15, 54-62], associated with dysexecutive and behavioral symptoms. More in detail, in the Helms's study [15] of 58 consecutive patients with acute respiratory distress syndrome (ARDS) and COVID-19 presenting with acute encephalopathy, $36 \%$ had dysexecutive syndrome with inattention, disorientation, or poorly organized movements in response to command. In a series of 4 severe COVID-19 patients who required ICU admission, cognitive impairment, identified as memory deficit and frontal syndrome, was detected [59]. Predominant executive and frontal lobe syndrome were also described by Delorme et al. [60] in 4 patients with COVID-related encephalopathy. Several reports describe aphasia and akinetic mutism as first symptoms of COVID encephalopathy [54-57, 61, 62], accompanied by manifestations consistent with dysexecutive syndrome and behavioral symptoms. Furthermore, in the case series of Beach et al. [15], three patients presented speech disturbances and akinetic mutism as prominent signs of COVID-related encephalopaty. Perrin et al. [63] reported further 5 patients with SARSCoV-2 infection presenting with acute encephalopathy including confusion, behavioral symptoms, language disturbances, and pyramidal signs. In the series of Paterson et al. [22], one patient presented speech disorder.

Frontal dysfunction has been also suggested by instrumental findings, with serial EEGs showing brain anterior slowing and perfusion MRI highlighting bilateral fronto-temporal hypoperfusion $[9,54,58,64-66]$. Systematic EEG studies are not available in COVID-19 patients, but of interest is the report of an EEG pattern characterized by non-reactive bifrontal monomorphic diphasic periodic delta slow waves, as a possible signature of SARS-CoV-2-related encephalopathy [66]. A spread frontal lobe hypometabolism on FDG-PET, first described by Cani et al. [54] in a patient with akinetc mutism related to COVID encephalopathy, has been subsequently reported in other 4 patients with COVID-19-related encephalopathy [61]. Unfortunately, FDG-PET has not been performed routinely in patients with COVID-related encephalopathy, thus larger cohorts are required to build up our knowledge of brain pathophysiological changes caused by SARS-CoV2. Brain MRI appears mostly not specific. A common finding consists in a diffuse hyperintensity of T2/fuid attenuated inversion recovery (FLAIR), most frequently in the white matter [67]. Of interest is the detection of abnormal contrast enhancement of the vascular wall in some patients [68] as a possible sign of a vascular inflammation process. In most of these patients, acute encephalopathy occurred some days after COVID infection, generally during the second week $[54,62$, 63]. Severe respiratory distress with mechanical ventilation was often detected $[9,54,68]$, even though not in all patients [62]. Most patients experienced cytokine release syndrome (CRS) before or during the onset of neurological manifestations [54, 62, 63]. Other possible causes of impaired consciousness - such as metabolic disorders including renal or hepatic insufficiency, dyselectrolytemia, hypoxemia, persistence of sedatives effects, or status epilepticus - were ruled out in these patients and could therefore not explain their clinical status. RT-PCR for SARS-CoV-2 in CSF as well as other brain infections turned out negative in all patients. The autoimmune encephalitis panel, when tested [54, 62, 63], was also negative. Of interest, CSF analysis showed the presence of blood-brain barrier (BBB) dysfunction and a CSF increase in IL-6-IL-8 levels, in parallel with cytokine level increase in serum $[54,62]$. Patients receiving immunotherapy, intravenous immunoglobulins and/or steroids, plasmapheresis, and tocilizumab [54-56, 59, 61, 68, 69] improved, but spontaneous recovery cannot be excluded, since COVID-19-related encephalopathy may have a self-limited course even without a specific therapy $[15,37,70]$. Unfortunately, very few studies assessed cytokine levels in both serum and CSF, in order to correlate disease course with cytokine levels following treatment. After specific treatment, when tested, reduction/stabilization in both CSF and serum cytokines was observed [54, 57,63].

Thus, in clinical, laboratory, and imaging findings, the absence of SARS-CoV-2 in the CSF and the benefits of intravenous steroid therapy and immunotherapy in COVID-19associated encephalopathy indicate an immune-mediated pathogenesis. In particular, a COVID-19-related encephalopathy secondary to cytokine-mediated neuroinflammation, at least for a subgroup of patients, has been suggested, pointing towards a parainfectious cytokine storm, post-infectious antibody-, or cell-mediated immune mechanism, rather than direct 
Table 1 COVID 19 encephalopathy: pathogenetic hypotheses

\begin{tabular}{|c|c|c|c|c|c|c|}
\hline & $\begin{array}{l}\text { Clinical } \\
\text { features }\end{array}$ & Mechanism & Course & Management & Outcome & $\begin{array}{l}\text { Putative neuropathological } \\
\text { findings }\end{array}$ \\
\hline $\begin{array}{l}\text { Secondary CNS } \\
\text { damage }\end{array}$ & $\begin{array}{l}\text { Not specific: } \\
\text { fever, } \\
\text { conscious- } \\
\text { ness } \\
\text { disorder, } \\
\text { delirium }\end{array}$ & $\begin{array}{l}\text { Indirect effect (fever, } \\
\text { hypoxia, } \\
\text { ischemia/hemorrhage, } \\
\text { metabolic derangement, } \\
\text { sepsis, toxins, } \\
\text { concurrent conditions) }\end{array}$ & Acute/subacute & $\begin{array}{l}\text { General } \\
\text { measures: } \\
\text { ventilatory } \\
\text { support, } \mathrm{O}_{2} \text {, } \\
\text { sedation, } \\
\text { antibiotics, } \\
\text { etc }\end{array}$ & Variable & $\begin{array}{l}\text { Hypoxic and ischemic } \\
\text { injuries }\end{array}$ \\
\hline $\begin{array}{l}\text { Direct CNS } \\
\text { invasion }\end{array}$ & $\begin{array}{l}\text { Not specific: } \\
\text { confusion } \\
\text { to coma, } \\
\text { headache, } \\
\text { seizures }\end{array}$ & $\begin{array}{l}\text { Direct invasion of the } \\
\text { CNS by SARS-CoV-2 }\end{array}$ & Acute & $\begin{array}{l}\text { Symptomatic } \\
\text { therapy: } \\
\text { steroids, } \\
\text { antiepileptic- } \\
\text { s, etc }\end{array}$ & $\begin{array}{l}\text { Unknown (few } \\
\text { reports) }\end{array}$ & $\begin{array}{l}\text { SARS-CoV-2 RNA and } \\
\text { proteins (rare) not associ- } \\
\text { ated with the severity of } \\
\text { neuropathological changes }\end{array}$ \\
\hline $\begin{array}{l}\text { Immunomediate } \\
\text { reaction to the } \\
\text { virus }\end{array}$ & $\begin{array}{l}\text { Prevalent } \\
\text { "Frontal" } \\
\text { symptoms } \\
\text { and } \\
\text { language } \\
\text { impairment }\end{array}$ & $\begin{array}{l}\text { Cytokine-mediated } \\
\text { neuroinflammatory } \\
\text { process }\end{array}$ & Few days & Immunotherapy & Reversal/attenuation & $\begin{array}{l}\text { Mild abnormalities with } \\
\text { inflammation by diffuse } \\
\text { astrocytes and microglia } \\
\text { activation and infiltration } \\
\text { of cytotoxic T } \\
\text { lymphocytes }\end{array}$ \\
\hline
\end{tabular}

viral neuro-invasion $[15,54,61-63]$. Cytokine release syndrome (CRS) is an exacerbated and dysregulated systemic inflammatory host response that can be triggered by COVID-19 [2, 25, 73]. The "cytokine storm" that involves increased levels of pro-inflammatory cytokines such as necrosis tumoral factor (TNF) and interleukin-6 (IL-6), among others, could cause endothelial dysfunction and BBB damage. The disruption of BBB favors the entry of pro-inflammatory cytokines in the CNS leading to neural and glial cells changes and damage $[71,72]$.

Interestingly, similar descriptions of acute cognitive impairment with diffuse cortical/frontal hypometabolism on FDG-PET/CT have been reported after therapy with chimeric antigen receptor $\mathrm{T}$ cells (CAR-T) [73], which are known to induce a cytokine storm [74]. CAR-T therapy represents an effective treatment for refractory hematologic malignancies, but unfortunately, it is burdened by a neurotoxicity syndrome called immune effector cell-associated neurotoxicity syndrome (ICANS) [75]. Expressive aphasia and speech impairment often represent the first manifestations of ICANS [76]. Similarly to COVID-19 encephalopathy, in most cases, ICANS occurs few days after the onset of CRS, exhibits frontal or diffuse theta-delta slowing on EEG and endothelial activation, systemic capillary leak, and subsequent dysfunction of the BBB. The last condition plays a crucial role in allowing the CSF to be exposed to systemic cytokines such as IL-1 and IL-6. CAR-T neurotoxicity could represent a reference model for cytokine-mediated neuroinflammation syndrome, as well as for its management. Preventive rather than reactive therapeutic strategies for CAR-T neurotoxicity are under study, i.e., by protecting endothelial cells and drugs blocking interleukin$1 \beta$, a macrophage-produced cytokine [77].
In summary, a distinctive form of encephalopathy could be associated with systemic hyperinflammation, mainly provoked by an aberrantly excessive innate immune response, triggered by COVID-19 infection. A frontal syndrome seems to be the predominant feature of this acute encephalopathy (at least in a subgroup of patients) and language disturbance could represent an early focal feature of a generalized CNS involvement. Serum and CSF cytokine levels may represent a good biomarker of the neurologic involvement as well as a useful basis for therapeutic strategies.

\section{Conclusive remarks ${ }^{3}$}

On the basis of abovementioned reports and observations, we can speculate that there are different possible mechanisms sustaining encephalopathy during COVID-19, in particular three main features may be taken into consideration, summarized in Table 1.

The first scenario is that of non-specific suffering of the $\mathrm{CNS}$, related to conditions triggered by severe infections, not different from etiologies other than COVID-19 and reasonably acting by means of an indirect effect on the CNS by fever, hypoxia, ischemia/hemorrhage, metabolic derangement, sepsis, toxins, and others, or a concurrent condition such as non-COVID-19 encephalitis (e.g., herpetic), thus appearing with clinical heterogeneous pictures, not permitting the clear definition of an encephalopathy specifically related to COVID- 19 .

\footnotetext{
${ }^{3}$ Due to AS.
} 
The second possibility is that of direct invasion of the CNS, manifesting with acute various but not specific neurologic signs or symptoms. Little evidence has been found in favor of this mechanism (i.e., the very rare finding of the virus in the $\mathrm{CNS}$ ), and probably it concerns a minority of cases.

The third hypothesis is that of an immunomediated reaction to the virus. This appears as the most intriguing idea, with the frequent appearance of a somewhat peculiar, if not specific, clinical feature, mainly represented by frontal manifestations and language impairment. From this point of view, the COVID-19 encephalopathy may present a very definite neurocognitive and behavioral picture, with a typical course evolving over few days from mild confusion to evident acute encephalopathy, potentially reversed or attenuated by immunotherapy. This feature shares many analogies with an immunomediated non-viral form of encepalopathy (ICANS), observed after CAR-T therapy for malignant hemopathies.

Thus, among aspecific neurocognitive manifestations related to acute COVID-19 infection, a frontal lobe presentation, according to a cytokine-mediated hyperinflammatory process, stands out, at least in a subgroup of patients. We are aware that no unifying definition of "cytokine storm" exists and that the COVID-19 encephalopathy inclusion in the spectrum of cytokine storm disorders needs more data. It is also unclear why this kind of encephalopathy - as well as ICANS - mainly presents with frontal and speech disorders. Thus, further research studies are required to confirm this hypothesis and a multicenter registry appears mandatory to collect and homogeneously study similar cases, in order to obtain relevant information about the specificity of this syndrome, as well as the underlying pathogenesis. Furthermore, trials should be carried out to investigate the efficacy of immunomodulatory therapies and interleukin/ interleukin-receptor antagonist in COVID-19-related encephalopathy. Finally, long-term sequelae of COVID-19 infection concerning residual or de novo cognitive and neurobehavioral problems deserve additional consideration in targeted studies to obtain new insights into the mechanisms of cerebral suffering due to COVID-19 infection.

Author contribution The authors state that they all equally had the idea for the article, performed the literature search, drafted, and/or critically revised the work.

\section{Declarations}

Ethical approval None

Informed consent statement None

Conflict of interest The authors declare no competing interests.

\section{References}

1. Guan WJ, Ni ZY, Hu Y, Liang W, Ou C, He J et al (2020) Clinical characteristics of coronavirus disease 2019 in China. N Engl J Med 382:1708-1720. https://doi.org/10.1056/NEJMoa2002032

2. Huang C, Wang Y, Li X, Ren L, Zhao J, Hu Y, Zhang L, Fan G, Xu J, Gu X, Cheng Z, Yu T, Xia J, Wei Y, Wu W, Xie X, Yin W, Li H, Liu M, Xiao Y, Gao H, Guo L, Xie J, Wang G, Jiang R, Gao Z, Jin Q, Wang J, Cao B (2020) Clinical features of patients infected with 2019 novel coronavirus in Wuhan, China. Lancet 395:497-506. https://doi.org/10.1016/S0140-6736(20)30183-5

3. Gupta A, Mahesh V, Madhavan MV, Sehgal K, Nair N, Mahajan S et al (2020) Extrapulmonary manifestations of COVID-19. Nat Med 26:1017-1032. https://doi.org/10.1038/s41591-020-0968-3

4. Lai CC, Ko WC, Lee PI, Jean SS, Hsueh PR (2020) Extrarespiratory manifestations of COVID-19. Int J Antimicrob Agents 56. https://doi.org/10.1016/j.ijantimicag2020.106024

5. Baj J, Karakuła-Juchnowicz H, Teresiński G, Buszewicz G, Ciesielka M, Sitarz E, Forma A, Karakuła K, Flieger W, Portincasa P, Maciejewski R (2020) COVID-19: specific and non-specific clinical manifestations and symptoms: the current state of knowledge. J Clin Med 9:1753. https://doi.org/10.3390/ jem9061753

6. Zheng KI, Feng G, Liu WY, Targher G, Byrne CD, Zheng MH (2020) Extrapulmonary complications of COVID-19: a multisystem disease? J Med Virol 2020:1-13. https://doi.org/10.1002/jmv. 26294

7. Chen X, Laurent S, Onur OA, Kleineberg NN, Fink GR, Schweitzer F, Warnke C (2020) A systematic review of neurological symptoms and complications of COVID-19. J Neurol 268: 392-402. https://doi.org/10.1007/s00415-020-10067-3

8. Mao L, Jin H, Wang M, Hu Y, Chen S, He Q, Chang J, Hong C, Zhou Y, Wang D, Miao X, Li Y, Hu B (2020) Neurological manifestations of hospitalized patients with COVID-19 in Wuhan. China JAMA Neurol 77:683-690. https://doi.org/10.1001/ jamaneurol.2020.1127

9. Helms J, Kremer S, Merdji H, Clere-Jehl R, Schenck M, Kummerlen C, Collange O, Boulay C, Fafi-Kremer S, Ohana M, Anheim M, Meziani F (2020) Neurologic features in severe SARSCoV-2 infection. N Engl J Med 2020(382):2268-2270. https://doi. org/10.1056/NEJMc2008597

10. Asadi-Pooya AA, Simani L (2020) Central nervous system manifestations of COVID-19: a systematic review. J Neurol Sci 413. https://doi.org/10.1016/j.jns.2020.116832

11. Ahmad I, Rathore FA (2020) Neurological manifestations and complications of COVID-19: a literature review. J Neurol Sci 77:8-12. https://doi.org/10.1016/j.jocn.2020.05.017

12. Benussi A, Pilotto A, Premi E, Libri I, Giunta M, Agosti C, Alberici A, Baldelli E, Benini M, Bonacina S, Brambilla L, Caratozzolo S, Cortinovis M, Costa A, Cotti Piccinelli S, Cottini E, Cristillo V, Delrio I, Filosto M, Gamba M, Gazzina S, Gilberti N, Gipponi S, Imarisio A, Invernizzi P, Leggio U, Leonardi M, Liberini P, Locatelli M, Masciocchi S, Poli L, Rao R, Risi B, Rozzini L, Scalvini A, Schiano di Cola F, Spezi R, Vergani V, Volonghi I, Zoppi N, Borroni B, Magoni M, Pezzini A, Padovani A (2020) Clinical characteristics and outcomes of inpatients with neurologic disease and COVID-19 in Brescia, Lombardy, Italy. Neurology 95: 910-920. https://doi.org/10.1212/WNL.0000000000009848

13. Leonardi M, Padovani A, McArthur JC (2020) Neurological manifestations associated with COVID-19: a review and a call for action. J Neurol 267:1573-1576. https://doi.org/10.1007/s00415020-09896-Z 
14. Pilotto A, Benussi A, Libri I, Masciocchi S, Poli L, Premi E, Alberici A, Baldelli E, Bonacina S, Brambilla L, Benini M, Caratozzolo S, Cortinovis M, Costa A, Cotti Piccinelli S, Cottini E, Cristillo V, Delrio I, Filosto M, Gamba M, Gazzina S, Gilberti N, Gipponi S, Giunta M, Imarisio A, Liberini P, Locatelli M, Schiano F, Rao R, Risi B, Rozzini L, Scalvini A, Vergani V, Volonghi I, Zoppi N, Borroni B, Magoni M, Leonardi M, Zanusso G, Ferrari S, Mariotto S, Pezzini A, Gasparotti R, Paolillo C, Padovani A (2020) COVID-19 impact on consecutive neurological patients admitted to the emergency department. J Neurol Neurosurg Psychiatry 92:218220. https://doi.org/10.1136/jnnp-2020-323929

15. Beach RS, Praschan NC, Hogan C, Dotson S, Merideth F, Kontos $\mathrm{N}$ et al (2020) Delirium in COVID-19: a case series and exploration of potential mechanisms for central nervous system involvement. Gen Hosp Psychiatry 65(2020):47-53. https://doi.org/10.1016/j. genhosppsych.2020.05.008

16. Whittaker A, Matthew Anson M (2020) Harky A (2020) Neurological manifestations of COVID-19: a systematic review and current update. Acta Neurol Scand 00:1-9. https://doi.org/10. 1111/ane.13266

17. Tsivgoulis G, Palaiodimous L, Katsanos AH, Caso V, Köhrmann M, Molina C et al (2020) Neurological manifestations and implications of COVID-19. Pandemic Ther Adv Neurol Disord 2020(13): 1-14. https://doi.org/10.1177/1756286420932036

18. Sharifian-Dorche M, Huot P, Osherov M, Wen D, Saveriano A, Giacomini PS et al (2020) Neurological complications of coronavirus infection: a comparative review and lessons learned during the COVID-19 pandemic. J Neurol Sci 417:117085. https://doi.org/10. 1016/j.jns.2020.117085

19. Pryce-Roberts A, Talaei M, Robertson NP Neurological complications of COVID-19: a preliminary review. J Neurol 267:1870 1873. https://doi.org/10.1007/s00415-020-09941-x

20. Niazkar HR, Zibaee B, Nasimi A, Narjes B (2020) The neurological manifestations of COVID-19: a review article. Neurol Sci doi https://doi.org/10.1007/s10072-020-04486-3

21. Ahmed MU, Hanif M, Ali MJ, Haider MA, Kherani D, Memon GM, Karim AH, Sattar A (2020) Neurological manifestations of COVID-19 (SARS-CoV-2): a review. Front Neurol 11:518. https://doi.org/10.3389/fneur.2020.00518

22. Paterson RW, Brown RL, Benjamin L, Nortley R, Wiethoff S, Bharucha T, Jayaseelan DL, Kumar G, Raftopoulos RE, Zambreanu L, Vivekanandam V, Khoo A, Geraldes R, Chinthapalli K, Boyd E, Tuzlali H, Price G, Christofi G, Morrow J, McNamara P, McLoughlin B, Lim ST, Mehta PR, Levee V, Keddie S, Yong W, Trip SA, Foulkes AJM, Hotton G, Miller TD, Everitt AD, Carswell C, Davies NWS, Yoong M, Attwell D, Sreedharan J, Silber E, Schott JM, Chandratheva A, Perry RJ, Simister R, Checkley A, Longley N, Farmer SF, Carletti F, Houlihan C, Thom M, Lunn MP, Spillane J, Howard R, Vincent A, Werring DJ, Hoskote C, Jäger HR, Manji H, Zandi MS (2020) The emerging spectrum of COVID-19 neurology: clinical, radiological and laboratory findings. Brain 143:3104-3120. https://doi. org/10.1093/brain/awaa240

23. Ellul MA, Benjamin L, Singh B, Lant S, Benedict DM, Easton A et al (2020) Neurological associations of COVID-19. Lancet Neurol 19:767-783. https://doi.org/10.1016/S1474-4422(20)30221-0

24. Matschke J, Lütgehetmann M, Hagel C, Sperhake JP, Schröder AS, Edler C, Mushumba H, Fitzek A, Allweiss L, Dandri M, Dottermusch M, Heinemann A, Pfefferle S, Schwabenland M, Sumner Magruder D, Bonn S, Prinz M, Gerloff C, Püschel K, Krasemann S, Aepfelbacher M, Glatzel M (2020 Nov) Neuropathology of patients with COVID-19 in Germany: a post- mortem case series. Lancet Neurol 19(11):919-929. https://doi.org/ 10.1016/S1474-4422(20)30308-2

25. Aghagoli G, Gallo Marin B, Katchur NJ, Chaves-Sell F, Asaad WF, Murphy SA (2020) Neurological involvement in COVID-19 and potential mechanisms: a review. Neurocrit Care 13:1-10. https:// doi.org/10.1007/s12028-020-01049-4

26. Ticinesi A, Cerundolo N, Parise A, Nouvenne A, Prati B, Guerra A et al (2020) Delirium in COVID-19: epidemiology and clinical correlations in a large group of patients admitted to an academic hospital. Aging Clin Exp Res 32:2159-2166. https://doi.org/10. 1007/s40520-020-01699-6

27. Rogers JP, Chesney E, Oliver D, Pollak TA, McGuire P, Fusar-Poli P, Zandi MS, Lewis G, David AS (2020) Psychiatric and neuropsychiatric presentations associated with severe coronavirus infections: a systematic review and meta-analysis with comparison to the COVID-19 pandemic. Lancet Psychiatry 7:611-627. https://doi. org/10.1016/S2215-0366(20)30203-0

28. Hsieh SJ, Soto GJ, Hope AA, Ponea A, Gong MN (2015) The association between acute respiratory distress syndrome, delirium, and in-hospital mortality in intensive care unit patients. Am J Respir Crit Care Med 191:71-78. https://doi.org/10.1164/rccm.201409$1690 \mathrm{OC}$

29. Hopkins RO, Weaver LK, Chan KJ, Orme JF Jr (2004) Quality of life, emotional, and cognitive function following acute respiratory distress syndrome. J Int Neuropsychol Soc 10:1005-1017. https:// doi.org/10.1017/s135561770410711x

30. Bianchetti A, Rozzini R, Guerini F, Boffelli S, Ranieri P, Minelli G, Bianchetti L, Trabucchi M (2020) Clinical presentation of COVID19 in dementia patients. J Nutr Health Aging 24:560-562. https://doi.org/10.1007/s12603-020-1389-1

31. Wilson MH, Newman S, Imray CH (2009) The cerebral effects of ascent to high altitudes. Lancet Neurol 8:175-191. https://doi.org/ 10.1016/S1474-4422(09)70014-6

32. Howard RS (2007) Neurological problems on the ICU. Clinical medicine (London, England) 7:148-153. https://doi.org/10.7861/ clinmedicine.7-2-148)

33. Pilotto A, Masciocchi S, Volonghi I, Crabbio M, Magni E, De Giuli V, Caprioli F, Rifino N, Sessa M, Gennuso M, Cotelli MS, Turla M, Balducci U, Mariotto S, Ferrari S, Ciccone A, Fiacco F, Imarisio A, Risi B, Benussi A, Premi E, Focà E, Caccuri F, Leonardi M, Gasparotti R, Castelli F, Zanusso G, Pezzini A (2021) Padovani A; SARS-CoV-2 related encephalopaties (ENCOVID) Study Group. Clinical presentation and outcomes of SARS-CoV-2 related encephalitis: the ENCOVID multicentre study. J Infect Dis 223(1): 28-37. https://doi.org/10.1093/infdis/jiaa609

34. Sasannejad C, Ely EW, Lahiri S (2019) Long-term cognitive impairment after acute respiratory distress syndrome: a review of clinical impact and pathophysiological mechanisms. Crit Care 23:352. https://doi.org/10.1186/s13054-019-2626-Z

35. Edén A, Kanberg N, Gostner J, Fuchs D, Hagberg L, Andersson LM, Lindh M, Price RW, Zetterberg H, Gisslén M (2020) CSF biomarkers in patients with COVID-19 and neurological symptoms: a case series. Neurology 12(96):e294-e300. https://doi.org/ 10.1212/WNL.0000000000010977

36. Politi LS, Salsano E, Grimaldi M (2020) Magnetic resonance imaging alteration of the brain in a patient with coronavirus disease 2019 (COVID-19) and anosmia. JAMA Neurol 77:1028-1029. https://doi.org/10.1001/jamaneurol.2020.2125

37. Eliezer M, Hamel AL, Houdart E, Herman P, Housset J, Jourdaine C, Eloit C, Verillaud B, Hautefort C (2020) Loss of smell in COVID-19 patients: MRI data reveals a transient edema of the olfactory clefts. Neurology. 95:e3145-e3152. https://doi.org/10. 1212/WNL.0000000000010806 
38. Lovati C, Osio M, Pantoni L (2020) Diagnosing herpes simplex-1 encephalitis at the time of COVID-19 pandemic. Neurol Sci 41: 1361-1364. https://doi.org/10.1007/s10072-020-04461-y

39. Scopelliti G, Osio M, Arquati M, Pantoni L (2020) Respiratory dysfunction as first presentation of myasthenia gravis misdiagnosed as COVID-19. Neurol Sci 17:1-3. https://doi.org/10.1007/s10072020-04826-3

40. Beatriz Lara B, Carnes A, Dakterzada F, Benitez I, Piñol-Ripoll G (2020) Neuropsychiatric symptoms and quality of life in Spanish Alzheimer's disease patients during COVID-19 lockdown. Eur J Neurol 27:1744-1747. https://doi.org/10.1111/ene.14339

41. Brooks SK, Webster RK, Smith LE, Woodland L, Wessely S, Greenberg N, Rubin GJ (2020) The psychological impact of quarantine and how to reduce it: rapid review of the evidence. Lancet 395(10227):912-920. https://doi.org/10.1016/S0140-6736(20) 30460-8

42. Pandharipande PP, Girard TD, Jackson JC, Morandi A, Thompson JL, Pun BT, Brummel NE, Hughes CG, Vasilevskis EE, Shintani AK, Moons KG, Geevarghese SK, Canonico A, Hopkins RO, Bernard GR, Dittus RS, Ely EW, BRAIN-ICU Study Investigators (2013) BRAIN-ICU study investigators. Long-term cognitive impairment after critical illness. N Engl J Med 369: 1306-1316. https://doi.org/10.1056/NEJMoa1301372

43. Zhou H, Lu S, Chen J, Wei N, Wang D, Lyu H, Shi C, Hu S (2020) The landscape of cognitive function in recovered COVID-19 patients. J Psychiatr Res 129:98-102

44. Negrini F, Ferrario I, Mazziotti D, Berchicci M, Bonazzi M, de Sire A, Negrini S, Zapparoli L (2021) Neuropsychological features of severe hospitalized COVID-19 patients at clinical stability and clues for post-acute rehabilitation. Arch Phys Med Rehabil 102: 155-158. https://doi.org/10.1016/j.apmr.2020.09.376

45. Almeria M, Cejudo JC, Sotoca J, Deus J, Krupinski J (2020) Cognitive profile following COVID-19 infection: clinical predictors leading to neuropsychological impairment. Brain Behav Immun Health 9:100163. https://doi.org/10.1016/j.bbih.2020. 100163

46. Steardo L, Zorec R, Verkhratsky A (2020) Neuroinfection may potentially contribute to pathophysiology and clinical manifestations of COVID-19. Acta Physiol (Oxford) 229:e13473. https:// doi.org/10.1111/apha.13473

47. Suzuki M, Saito K, Min W-P, Vladau C, Toida K, Itoh H, Murakami S (2007) Identification of viruses in patients with postviral olfactory dysfunction. Laryngoscope 117:272-277. https://doi.org/10.1097/01.mlg.0000249922.37381.1e

48. TWH C, Sridhar S, Zhang AJ, Chan KH, Li HL, FKC W, Yuen KY (2020) Olfactory dysfunction in coronavirus disease 2019 patients: observational cohort study and systematic review. Open Forum Infect Dis 7:ofaa199. https://doi.org/10.1093/ofid/ofaa199

49. Lechien JR, Chiesa-Estomba CM, De Siati DR, Horoi M, Le Bon SD, Rodriguez A et al (2020) Olfactory and gustatory dysfunctions as a clinical presentation of mild-to-moderate forms of the coronavirus disease (COVID-19): a multicenter European study. Eur Arch Otorhinolaryngol 277:2251-2261. https://doi.org/10.1007/s00405020-05965-1

50. Neumann B, Schmidbauer ML, Dimitriadis K, Otto S, Knier B, Niesen WD, Hosp JA, Günther A, Lindemann S, Nagy G, Steinberg T, Linker RA, Hemmer B, Bösel J, PANDEMIC and the IGNITE study groups (2020) Cerebrospinal fluid findings in COVID-19 patients with neurological symptoms. J Neurol Sci 418:117090. https://doi.org/10.1016/j.jns.2020.117090

51. Muus C, Luecken MD, Eraslan G, Waghray A, Heimberg G, Sikkema L et al (2020) Integrated analyses of single-cell atlases reveal age, gender, and smoking status associations with cell type-specifc expression of mediators of SARS-CoV-2 viral entry and highlights infammatory programs in putative target cells.
bioRxiv 04(19):049254. https://doi.org/10.1101/2020.04.19. 049254

52. Varatharaj A, Thomas N, Ellul MA, Davies NWS, Pollak TA, Tenorio EL (2020) Neurological and neuropsychiatric complications of COVID-19 in 153 patients: a UK-wide surveillance study. Lancet Psychiatry 7:875-882. https://doi.org/10.1016/S22150366(20)30287-X

53. Zayet S, Ben Abdallah Y, Royer PY, Toko L, Gendrin V, Klopfenstein T (2020) Encephalopathy in patients with COVID19: “causality or coincidence?". J Med Virol 93:1193. https://doi. org/10.1002/jmv.26027

54. Cani I, Barone V, D’Angelo R, Pisani L, Allegri V, Spinardi L, Malpassi P, Fasano L, Rinaldi R, Fanti S, Cortelli P, Guarino M (2020) Frontal encephalopathy related to hyperinflammation in COVID-19. J Neurol 11:1-4. https://doi.org/10.1007/s00415-02010057-5

55. Muccioli L, Pensato U, Cani I, Guarino M, Cortelli P, Bisulli F (2020) COVID-19-associated encephalopathy and cytokinemediated neuroinflammation. Ann Neurol 88:860-861. https:// doi.org/10.1002/ana.25855

56. Pensato U, Muccioli L, Pasini E, Tappatà M, Ferri L, Volpi L, Licchetta L, Battaglia S, Rossini G, Bon I, Re MC, Cirillo L, Simonetti L, Gramegna LL, Michelucci R, Cortelli P, Zini A, Bisulli F (2020) Encephalopathy in COVID-19 presenting with acute aphasia mimicking stroke. Front Neurol 11:587226. https:// doi.org/10.3389/fneur.2020.587226

57. Koralnik IJ, Tyler KL (2020) COVID-19: a global threat to the nervous system. Ann Neurol 88:1-11. https://doi.org/10.1002/ana. 25807

58. Muccioli L, Pensato U, Cani I, Guerra L, Provini F, Bordin G, Riccioli LA, Lodi R, Tinuper P, Bisulli F (2020) COVID-19related encephalopathy presenting with aphasia resolving following tocilizumab treatment. J Neuroimmunol 349:577400. https://doi. org/10.1016/j.jneuroim.2020.577400

59. Chaumont H, San-Galli A, Martino F, Couratier C, Joguet G, Carles M, Roze E, Lannuzel A (2020) Mixed central and peripheral nervous system disorders in severe SARS-CoV-2 infection. J Neurol 267:3121-3127. https://doi.org/10.1007/s00415-020-09986-y

60. Delorme C, Paccoud O, Kas A, Hesters A, Bombois S, Shambrook P, Boullet A, Doukhi D, le Guennec L, Godefroy N, Maatoug R, Fossati P, Millet B, Navarro V, Bruneteau G, Demeret S, Pourcher $\mathrm{V}$, the CoCo-Neurosciences study group and COVID SMIT PSL study group (2020) COVID-19-related encephalopathy: a case series with brain FDG-positron-emission tomography/computed tomography findings. Eur J Neurol 27:2651-2657. https://doi.org/10. 1111/ene. 14478

61. Filatov A, Sharma P, Hindi F, Espinosa PS (2020) Neurological complications of coronavirus disease (COVID-19) encephalopathy. Cureus 12:7352. https://doi.org/10.7759/cureus.7352

62. Pilotto A, Odolini S, Masciocchi S, Comelli A, Volonghi I, Gazzina S, Nocivelli S, Pezzini A, Focà E, Caruso A, Leonardi M, Pasolini MP, Gasparotti R, Castelli F, Ashton NJ, Blennow K, Zetterberg H, Padovani A (2020) Steroid-responsive encephalitis in coronavirus disease 2019. Ann Neurol 88:423-427. https://doi.org/10.1002/ana. 25783

63. Perrin P, Collongues N, Baloglu S, Bedo D, Bassand X, Lavaux T, Gautier-Vargas G, Keller N, Kremer S, Fafi-Kremer S, Moulin B, Benotmane I, Caillard S (2021) Cytokine release syndromeassociated encephalopathy in patients with COVID-19. Eur J Neurol 28:248-258. https://doi.org/10.1111/ene.14491

64. Galanopoulou AS, Ferastraoaru V, Correa DJ, Cherian K, Duberstein S, Gursky J, Hanumanthu R, Hung C, Molinero I, Khodakivska O, Legatt AD, Patel P, Rosengard J, Rubens E, Sugrue W, Yozawitz E, Mehler MF, Ballaban-Gil K, Haut SR, Moshé SL, Boro A (2020) EEG findings in acutely ill patients investigated for SARS-CoV-2/COVID-19: a small case series 
preliminary report. Epilepsia Open 5:314-324. https://doi.org/10. 1002/epi4.12399

65. Pasini E, Bisulli F, Volpi L, Minardi I, Tappatà M, Muccioli L, Pensato U, Riguzzi P, Tinuper P, Michelucci R (2020) EEG findings in COVID-19 related encephalopathy. Clin Neurophysiol 131: 2265-2267. https://doi.org/10.1016/j.clinph.2020.07.003

66. Vellieux G, Rouvel-Tallec A, Jaquet P, Grinea A, Sonneville R, d'Ortho MP (2020) COVID-19 associated encephalopathy: is there a specific EEG pattern? Clin Neurophysiol 131:1928-1930. https:// doi.org/10.1016/j.clinph.2020.06.005

67. Shiahaan YMT, Puspitasari V, Rinaldi Pangestu A. (2020) COVID-19-associated encephalitis: systematic review of case reports. Findings on Cytokine Immune-Mediated Inflammation as an Underlying Mechanism. Research Square https://orcid.org/00000003-3785-3077 DOI: 10.21203/rs.3.rs-65579/v1

68. Pugin D, Vargas MI, Thieffry C, Schibler M, Grosgurin O, Pugin J, Lalive PH (2020) COVID-19-related encephalopathy responsive to high doses glucocorticoids. Neurology 95:543-546. https://doi.org/ 10.1212/WNL.0000000000010354

69. Dogan L, Kaya D, Sarikaya T, Zengin R, Dincer A, Akinci IO, Afsar N (2020) Plasmapheresis treatment in COVID-19-related autoimmune meningoencephalitis: case series. Brain Behav Immun 87:155-158. https://doi.org/10.1016/j.bbi.2020.05.022

70. Bernard-Valnet R, Pizzarotti B, Anichini A, Demars Y, Russo E, Schmidhauser M, Cerutti-Sola J, Rossetti AO, du Pasquier R (2020) Two patients with acute meningoencephalitis concomitant with SARS-CoV-2 infection. Eur J Neurol 27:43-44. https://doi. org/10.1111/ene. 14298

71. Zhang C, Wu Z, Li JW, Zhao H, Wang GQ (2020) Cytokine release syndrome in severe COVID-19: interleukin-6 receptor antagonist tocilizumab may be the key to reduce mortality. Int J Antimicrob Agents 55:105954. https://doi.org/10.1016/j.ijantimicag.2020. 105954

72. Majid F, Ali M, Somayeh M, Cyrus R (2020) Neurobiology of COVID-19. J Alzheimers Dis 76:3-19. https://doi.org/10.3233/ JAD-200581
73. Rubin DB, Danish HH, Ali AB, Li K, LaRose S, Monk AD, Cote DJ, Spendley L, Kim AH, Robertson MS, Torre M, Smith TR, Izzy S, Jacobson CA, Lee JW, Vaitkevicius H (2019) Neurological toxicities associated with chimeric antigen receptor T-cell therapy. Brain 142:1334-1348. https://doi.org/10.1093/brain/awz053

74. Santomasso B, Bachier C, Westin J, Rezvani K, Shpall EJ (2019) The other side of CAR T-cell therapy: cytokine release syndrome, neurologic toxicitly, and financial burden. Am Soc Clin Oncol Educ Book 39:433-444. https://doi.org/10.1200/EDBK_238691

75. Lee DW, Santomasso BD, Locke FL, Ghobadi A, Turtle CJ, Brudno JN, Maus MV, Park JH, Mead E, Pavletic S, Go WY, Eldjerou L, Gardner RA, Frey N, Curran KJ, Peggs K, Pasquini M, DiPersio JF, van den Brink MRM, Komanduri KV, Grupp SA, Neelapu SS (2019) ASTCT consensus grading for cytokine release syndrome and neurologic toxicity associated with immune effector cells. Biol Blood Marrow Transplant 25:625-638. https://doi.org/ 10.1016/j.bbmt.2018.12.758

76. Santomasso BD, Park JH, Salloum D, Riviere I, Flynn J, Mead E, Halton E, Wang X, Senechal B, Purdon T, Cross JR, Liu H, Vachha B, Chen X, DeAngelis LM, Li D, Bernal Y, Gonen M, Wendel HG, Sadelain M, Brentjens RJ (2018) Clinical and biological correlates of neurotoxicity associated with CAR T-cell therapy in patients with B-cell acute lymphoblastic leukemia. Cancer Discov 8:958971. https://doi.org/10.1158/2159-8290.CD-17-1319

77. Strati P, Ahmed S, Kebriaei P, Nastoupil LJ, Claussen CM, Watson G, Horowitz SB, Brown ART, Do B, Rodriguez MA, Nair R, Shpall EJ, Green MR, Neelapu SS, Westin JR (2020) Clinical efficacy of anakinra to mitigate CAR T-cell therapy-associated toxicity in large B-cell lymphoma. Blood Adv 4:3123-3127. https://doi.org/ 10.1182/bloodadvances.2020002328

Publisher's note Springer Nature remains neutral with regard to jurisdictional claims in published maps and institutional affiliations. 